\title{
Effects of grinding, pelleting and expanding on nutritive value of barley in pig diets
}

\begin{abstract}
MATTI NÄSI
NÄSI, M. 1992. Effects of grinding, pelleting and expanding on nutritive value of barley in pig diets. Agric. Sci. Finl. 1: 461-469. (Univ. Helsinki, Dept. Anim. Sci., SF-00710 Helsinki, Finland.)

Nutrient digestibility and protein utilization responses of growing pigs to different processes of barley were evaluated. The assayed treatments of barley were grinding methods: hammer milling (HM) and rolling (RM), pelleting (HP, RP), expanding (HE, RE) and their combination (HEP, REP). The study comprised a $8 \times 8$ Latin square designed digestibility and nitrogen balance trial with a $2 \times 2 \times 2$ factorial arrangement of treatments. The average grist size of HM barley was smaller and wider than that of RM. Pelleting and expanding reduced the grist size and made the distribution wider compared to untreated ones. HM compared to RM achieved improved pellet quality, but expanding had no effect on pellet durability. Only small differences were found in the proximate composition or sugar content indicating a gelatinization degree of differently processed barleys. Grinding method had no effect on organic matter (OM) digestibility, whereas $\mathrm{RM}$ improved protein $(\mathrm{CP})$ digestibility $(\mathrm{P}<0.001)$ but led to lower ether extract $(\mathrm{EE})$ digestibility $(\mathrm{P}<0.001)$. Pelleting significantly improved digestibility of all barley constituents $(\mathrm{P}<0.01,0.001)$, the magnitude being 0.02 compared to meal form barley. A significant interaction between the grinding method and pelleting was noticed in $\mathrm{CP}(\mathrm{P}<0.05)$ and $\mathrm{EE}(\mathrm{P}<0.001)$ digestibility. Except for the digestibility of crude fibre $(\mathrm{P}<0.001)$, there were no significant differences between the treatments in response to the expanding process of barley. Significant interactions in digestibilities were found between grinding methods and expanding. RM compared to $\mathrm{HM}$ achieved significantly higher $\mathrm{N}$-retention $(\mathrm{P}<0.001)$ and protein utilization $(\mathrm{P}<0.001)$ and decreased urinary urea-N excretion $(\mathrm{P}<0.001)$. Pelleting significantly improved protein absorption $(\mathrm{P}<0.001)$ and tended to decrease urinary- $\mathrm{N}$ excretion, but $\mathrm{N}$-retention was unaffected by the physical form of the barley. Expanding had no effect on protein absorption or $\mathrm{N}$-retention, but achieved a small significant improvement in biological value of protein $(\mathrm{P}<0.01)$.
\end{abstract}

Key words: grinding, pelleting, expanding, digestibility, nitrogen balance, pig, barley

\section{Introduction}

The major contribution of barley in pig diets has stimulated the development of various techniques for grain processing in order to increase the efficiency of utilization of dietary nutrients and pig performance. Barley has rather high total fibre con- tent including both insoluble and soluble fibre (Åman and Hesselman 1984). Thus, it is important to reduce particle size or by some other processing means to increase accessibility to the digestive enzymes of the pig.

Cereal grains are not all completely broken down during mastication and some may pass unutilized 
through the alimentary tract. Fineness of grind will affect utilization of grain. It has been shown that screen sizes of up to five mm diameter are unlikely to impair utilization significantly, but screen size of nine $\mathrm{mm}$ or above will have a deleterious effect (LAWRENCE 1970, SimONSSON 1978a). Compared with this, efficient rolling, so that each grain is throughout flattened, would appear capable of eliciting as efficient a response as any of the grinding procedures when using screen sizes up to five mm diameter (LAWRENCE 1978, SimONSSON 1978b). There is evidence of a relationship between cereal particle size and ulceration, the finer the grinding the higher the incidence of ulceration in the oesophageal region of the pig (LAWRENCE 1972, SIMONSSON and BJöRKLUND 1978, KIRCHGESSNER et al. 1985).

The use of pelleted feeds for pigs is associated with an improvement in feed utilization efficiency, due principally to reduced feed wastage and improved nutrient digestibility. It has been proposed that the following are the advantages of pelleted over meal feeds: reduced selective feeding, reduced segregation, increased bulk density and improved handling and flowability. A tendency for digestibility of nutrients and performance of pigs to improve has been noticed when the fibre content of the diet is increased (VANSCHOUBROEK et al. 1971, LAWRENCE 1983).

With the expander, it is possible to achieve higher temperatures and pressures compared to a conventional pellet mill. The advantages of a combination of expander and pellet mill are claimed to be: improved pellet quality, digestibility and reduction of bacteria (WETTSTEIN and WILD 1990).
Three of the more important production technologies in producing pig feeds will be dealt with here: grinding, pelleting and expanding and their combinations of treating barley. The objectives of the current study were to investigate the effects of various processes on nutrient digestibility and protein utilization in pigs fed barley based diets. A subsequent study where performance and oesophagogastric lesion responses of pigs to hammer milled and rolled barley diets were investigated will be published by AlAviUHKOLA et al. (to be publ.)

\section{Material and methods}

The processing treatments of barley were two grinding methods, pelleting, expanding and their combination. The hammer milling was made with a peripherally fed mill, $1500 \mathrm{rpm}$ to pass $3.5 \mathrm{~mm}$ sieve (HM) and the roll milling with a smooth roller (RM). Both of the ground barleys were divided into two baches, of which one was pelleted with a Bühler DPGC mill, to yield pellets of $4.5 \mathrm{~mm}$ diameter, at temperature of $65^{\circ} \mathrm{C}(\mathrm{HP}, \mathrm{RP})$. Then, a part of each of the the bathes was either expanded (Kahl expander, temperature $95-100^{\circ} \mathrm{C}$ (HE, RE) or pelleted after expanding (HEP, REP). The grist spectrum of the barleys after different treatments is outlined in Table 1. They were measured with a test sieve shaker for $5 \mathrm{~min}$ after soaking $50 \mathrm{~g}$ feed in $250 \mathrm{ml}$ water for $2 \mathrm{~h}$ and rinsing with water during sieving. Oversized feed on the sieves was kept at room temperature overnight and weighted. Quality of the pellets was measured by screening and counting the proportion of whole pellets retained on the

Table 1. Particle size distribution of differently treated barley.

\begin{tabular}{|c|c|c|c|c|c|c|c|c|}
\hline Particle diameter, $\mathrm{mm}$ & $\mathrm{HM}$ & HP & HEP & $\mathrm{HE}$ & RM & RP & REP & RE \\
\hline $4.0<$ & - & - & - & - & 0.306 & 0.006 & - & 0.004 \\
\hline $1.6-4.0$ & 0.104 & 0.140 & 0.178 & 0.186 & 0.354 & 0.414 & 0.312 & 0.372 \\
\hline $1.0-1.6$ & 0.228 & 0.244 & 0.224 & 0.144 & 0.074 & 0.182 & 0.196 & 0.186 \\
\hline $0.3-1.0$ & 0.332 & 0.314 & 0.304 & 0.280 & 0.050 & 0.152 & 0.164 & 0.138 \\
\hline$<0.3$ & 0.336 & 0.302 & 0.294 & 0.390 & 0.216 & 0.246 & 0.328 & 0.300 \\
\hline
\end{tabular}

The treatments: hammer milling (HM), rolling (RM), pelleting of hammer milled and rolled (HP, RP), expanding of hammer milled and rolled (HE, RE) and the combination of expanding and pelleting of hammer milled anf rolled (HEP, REP) 
$4 \mathrm{~mm}$ screen. The pellets were circulated for $1 \mathrm{~min}$ in a pneumatic transfer with a Holmen pellet tester.

A $8 \times 8$ balanced Latin square with growing pigs of castrated males (Landrace x Large White), initial weight of 28.6 (SE 1.85) $\mathrm{kg}$ and final weight of 97.4 (SE 3.75 ) $\mathrm{kg}$ with a $2 \times 2 \times 2$ factorial arrangement of treatments, was carried out to determine the effects of grinding, pelleting and expanding and their combinations on nutrient digestibility and protein utilization of barley based diets. Eight dietary treatments were used and the diets consisted of treated barley $850 \mathrm{~g} / \mathrm{kg}$ and soybean meal $150 \mathrm{~g} / \mathrm{kg}$. The pigs were fed twice daily according to a restricted feeding regime and their diets were adequately fortified with minerals and vitamins (SALO et al. 1990). The pigs were kept during the whole experiment in metal metabolism cages equipped with collection trays, allowing separate collection of faeces and urine. Each period comprised 5 days of adjustment and 5 days of total collection of faeces and urine. The details of the procedure are the same as described by Näsı (1984). All animals completed the experiment successfully and the average daily weight gain during the entire experiment was $860 \mathrm{~g}$. No differences in palatability of the variously treated barley diets were observed. Refusals of the diet were negligible.

The digestibilities of the barleys treated with different processes were calculated by difference method. Feed values of the ingredients were computed according to SALO et al. (1990) and ANDERSEN and Just (1983). The data were analyzed by analysis of variance $8 \times 8$ Latin square with a $2 \times 2 \times 2$ factorial arrangement of treatments. The sums of squares for treatment effect were further separated into single degrees of freedom for comparisons of the dietary treatments (SNEDECOR and COCHRAN 1967).

\section{Results and discussion}

Barley ground in a roller mill had a considerably coarser average grist size. The particle distribution of rolled barley was more narrow compared to hammer milled, but pelleting and expanding reduced the grist size and made the distribution wider
(Table 1). Pellet durability was measured as a proportion of meal passing through a $4 \mathrm{~mm}$ sieve. The mealy proportions were $0.10,0.12,0.19$ and 0.19 for treatments HP, HEP, RP and REP, respectively. Prior to pelleting, hammer milled compared to rolled barley achieved better pellet quality. The average particle size of the ground product has an influence on pellet quality. In many cases, pellet quality can be improved most economically by reducing the average particle size. With an expander the temperatures and pressures are higher than in pellet die, thus it could be expected that pellet durability is improving the pelleting followed after expanding. Here pellet quality was unaffected probably due to low process temperature and limited use of steam, which is in accordance with the gelatination degree judged from sugar content.

Only small differences were found in the proximate composition of differently processed barleys (Table 2). HM-barley had a little higher crude protein content compared to the others. The preliminary samples taken after processing were similar, thus higher content is caused by some contamination when transported. Rolled barleys showed a little higher fibre content compared to milled ones. Only a small variation is shown in sugar or starch contents of treated barleys, indicating only a minor gelatinization effect from heating in pelleting or expanding processes. The gelatinization temperature of barley starch is relative low $59-64^{\circ} \mathrm{C}$ (DoGgETT 1970), but here the actual hydrothermal stage of the processing was rather short and the moisture content was quite low for higher gelatinization.

Grinding method had no effect on organic matter or carbohydrate digestibility (Tables 3 and 4). However, rolling led to better crude protein digestibility $(\mathrm{P}<0.001)$, although resulting in lower ether extract digestibility $(\mathrm{P}<0.001)$. This is supported by the observation that larger grist sizes of barley, ground by roller milling, has been utilized to the same extent as the smaller grist sizes, resulting from a peripherally fed hammer mill (SIMONSSON 1978a). Neither did LAWRENCE (1970) find differences in performance of pigs given diets containing 
Table 2. The chemical composition of the experimental feeds.

\begin{tabular}{|c|c|c|c|c|c|c|c|c|c|}
\hline $\begin{array}{l}\text { Treatment of feed } \\
\text { Composition, g/kg DM }\end{array}$ & $\mathrm{HM}$ & HP & HEP & $\mathrm{HE}$ & RM & RP & REP & RE & $\begin{array}{r}\text { Soy } \\
\text { bean } \\
\text { meal }\end{array}$ \\
\hline Dry matter & 868 & 864 & 861 & 853 & 862 & 860 & 859 & 849 & 871 \\
\hline Ash & 32 & 27 & 26 & 28 & 29 & 27 & 26 & 27 & 70 \\
\hline Crude protein & 133 & 120 & 116 & 116 & 121 & 119 & 119 & 119 & 491 \\
\hline Ether extract & 39 & 37 & 36 & 36 & 37 & 37 & 36 & 37 & 33 \\
\hline Crude fibre & 49 & 44 & 47 & 52 & 50 & 49 & 44 & 45 & 55 \\
\hline Nitrogen free extract & 747 & 772 & 775 & 769 & 764 & 767 & 774 & 773 & 352 \\
\hline NDF & 180 & 177 & 181 & 194 & 197 & 197 & 179 & 183 & 114 \\
\hline $\mathrm{ADF}$ & 42 & 39 & 42 & 48 & 45 & 47 & 41 & 41 & 47 \\
\hline Hemicellulose & 138 & 138 & 139 & 146 & 152 & 150 & 139 & 142 & 67 \\
\hline Starch & 539 & 602 & 597 & 581 & 555 & 555 & 567 & 583 & - \\
\hline Sugars & 43 & 45 & 42 & 41 & 44 & 43 & 41 & 42 & - \\
\hline
\end{tabular}

The treatments: hammer milling (HM), rolling (RM), pelleting of hammer milled and rolled (HP, RP), expanding of hammer milled and rolled (HE, RE) and the combination of expanding and pelleting of hammer milled anf rolled (HEP, REP)

barley which had been either rolled or ground to widely different degrees. Efficient rolling may overcome most of the problems caused by fine grind eg. dusty, unpalatable, sticky and pasty in the mouth of a pig, and gastric lesions. The rolling mill has been found to achieve rolled grain pores which are made up of fissures and cavities in the particle. These pores increase the surface area of a particle. Pore size distribution of HM- and RM-barleys was measured with a Hg-porosimeter, and the preliminary observations showed RM-barley to have very many small pores (Unpubl.). Total pore volume and pore size distribution can also be determined from gas absorption isotherms. External and pore surfaces may have a significant effect over a wide range of phenomena, particularly ad- and absorption of liquids and enzymes, which determines digestibility as well as particle size.

Pelleting significantly improved $(\mathrm{P}<0.01,0.001)$ digestibility of all the organic constituents, the magnitude being approximately 0.02 compared to meal form barley. A significant interaction between the grinding method and pelleting was noticed in $\mathrm{CP}(\mathrm{P}<0.05)$ and $\mathrm{EE}(\mathrm{P}<0.001)$ digestibility. In the pelleting process, cereals are subjected to pressure of being forced through the die of the pelleter. There is a frictional heating effect and excess, but prior to this, the grain is steam heated. Pelleting appears to modify molecular fractions of the feed. This is suggested from the fact that when pellets have been ground into meal before being fed, the beneficial effect of pelleting has still been obtained. Both chemical and physical changes are indicated which are involved in improving digestibility (LAWRENCE 1978).

The extensive review prepared by VANSCHOUBROEK et al. (1971) indicated that feeding of pelleted rations results in significant responses in the performance and food utilization in growing pigs. Present results are in accordance with data presented by LAWRENCE (1970) who found pelleting to improve dry matter and energy digestibility. The physical form of the diet, however, had only a small non-significant effect on the digestibility of energy and ME/DE ratio according to the data of PATTERSON (1989). The digestibility of nitrogen was significantly improved by pelleting, and nitrogen retention was also increased but not significantly (PAtterson 1989). Furthermore, Yen et al. (1971) found improved amino acid digestibility, which is in accordance with present results. Rarely is the cereal component subjected to pelleting alone. The effects of pelleting on the complete diet could be different, as here, when barley was alone. The effect of pelleting varies according to the method, pelleting cold versus steam. Sкосн et al. (1983) 

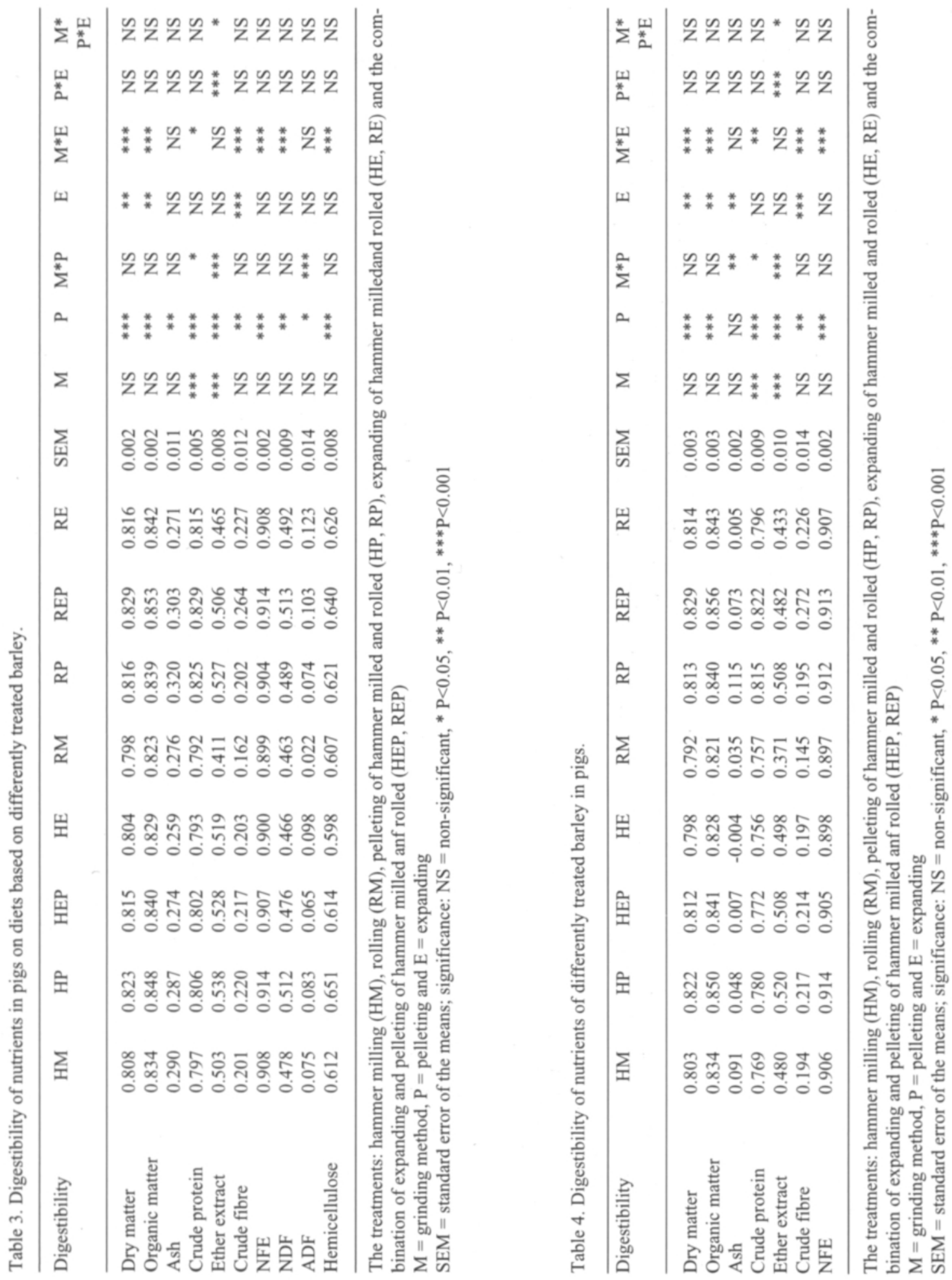


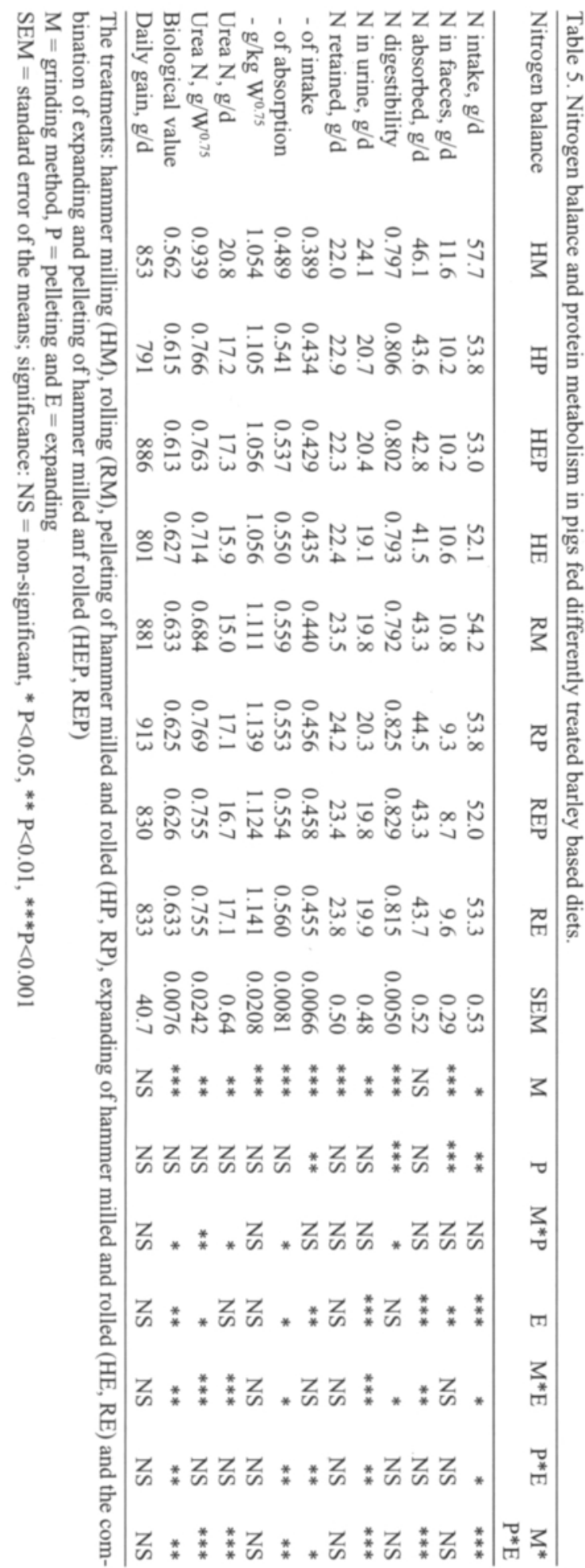

reported improvements in FCR of 0.071 and 0.055 of cold and steam-press pellets, respectively, in comparison to meal with increases in energy of 0.018 and 0.016 .

Except for the digestibility of crude fibre $(\mathrm{P}<0.001)$, there were no significant differences between the treatments in response of other nutrients to expanding process of barley. Significant interactions in digestibilities of $\mathrm{CP}(\mathrm{P}<0.01)$, CF and NFE $(\mathrm{P}<0.001)$ were found between grinding methods and expanding. Pigs fed extruded barley diet have had higher ileal digestibility for dry matter, energy and starch, but no significant differences in faecal digestibility were found (FADEL et al. 1988), which is in accordance with the present data. Extrusion of yellow corn or corn and wheat middling diet has been found to improve energy and DM digestibility, but has not affected the digestibility of lysine or $\mathrm{N}$ at the terminal ileum (Sкосн et al. 1983, Herkelman et al. 1990). Expanding and extrusion are rather similar processes, despite stronger hydrothermal effect in the extruder. An improvement of 0.13 over the controls in daily gain of piglets fed expanded diet has been reported by BOLDUAN and PEISKer (1992), but product temperature of $115^{\circ} \mathrm{C}$ was higher than in present treatment. The thermal processing of the present expanding treatment proved to be quite slight, so that the effect on nutrient digestibilies was weak.

The results of the $\mathrm{N}$ balance and various calculated parameters of protein utilization are shown in Table 5. Rolling of barley compared to hammer milling achieved significantly higher $\mathrm{N}$-absorption $(\mathrm{P}<0.001)$ and lower urinary- $\mathrm{N}$ and urea- $\mathrm{N}$ excretion $(\mathrm{P}<0.01)$. A rolled barley diet gave significantly higher N-retention (22.4 vs. $23.7 \mathrm{~g} / \mathrm{d}$, $\mathrm{P}<0.001)$ and proportions of $\mathrm{N}$-retention in relation to intake of $\mathrm{N}$ were improved by $0.03(\mathrm{P}<0.001)$. Biological value is significantly higher on the rolled barley diet, which was in accordance with the tendency of improved daily gain.

Pelleting of barley improved diet N-digestibility $(\mathrm{P}<0.001)$ and tended to decrease urinary- $\mathrm{N}$ excretion $(\mathrm{P}<0.1)$. N-retention was unaffected by the 
Table 6. Calculated feed values of the differently treated barleys.

\begin{tabular}{lrrrrrrrr}
\hline Feed value & HM & HP & HEP & HE & RM & RP & REP & RE \\
\hline FU/kg DM & 1.118 & 1.147 & 1.135 & 1.116 & 1.098 & 1.132 & 1.152 & 1.133 \\
FU/kg & 0.97 & 0.99 & 0.97 & 0.95 & 0.95 & 0.97 & 0.99 & 0.96 \\
DCP g/kg DM & 103 & 94 & 89 & 87 & 91 & 97 & 98 & 95 \\
DCP g/FU & 92 & 82 & 79 & 78 & 83 & 86 & 85 & 83 \\
ME MJ/kg DM & 14.70 & 15.03 & 14.84 & 14.59 & 14.39 & 14.85 & 15.11 & 14.84 \\
NE MJ/kg DM & 9.14 & 9.39 & 9.25 & 9.06 & 8.91 & 9.26 & 9.45 & 9.25 \\
FE $_{\text {s }}$ & 1.184 & 1.216 & 1.198 & 1.174 & 1.154 & 1.199 & 1.225 & 1.19 \\
\hline
\end{tabular}

The treatments: hammer milling (HM), rolling (RM), pelleting of hammer milled and rolled (HP, RP), expanding of hammer milled and rolled (HE, RE) and the combination of expanding and pelleting of hammer milled anf rolled (HEP, REP) $\mathrm{FU}=$ feed units, $0.7 \mathrm{~kg}$ starch equivalent, $\mathrm{DCP}=$ digestible crude protein, $\mathrm{ME}=$ metabolizable energy, $\mathrm{NE}=$ net energy, FEs $=$ Danish net energy system for pigs

physical form of the barley. Protein utilization was improved by pelleting to a small degree. The observation is similar to that of PATTERSON (1989). Daily gain of the pigs fed on a pelleted diet improved 842 vs $855 \mathrm{~g} / \mathrm{d}$, being consistent with earlier results given in the literature. The better performance of pigs fed a pelleted diet over meal form has obviously resulted from the higher digestibility of energy yielding components and from avoiding most of the feed wastage rather than improved protein utilization.

Expanding had no effect on N-digestibility or Nretention. Urinary-N excretion $(\mathrm{P}<0.001)$ and parameters indicating protein utilization $(\mathrm{P}<0.01,0.05)$ were improved by using an expander as a treatment. In contrast to this, the daily gain was slightly inferior in pigs fed expanded barley compared to untreated ones. There was a small difference in the $\mathrm{N}$-intake which may have had an effect on the parameters measured. Hydrothermal processes are directed to rupture cell wall matrix and modify the chemical structure of cereal constituents. These processes are aimed at rendering nutrients more susceptible to enzyme degradation in the small intestine, thus improving the digestibility and utilization, especially amino acids. Two explanations for the lack of response could be either that the expanding process was too mild or that no further improvement can be achieved in the endogenous enzymes of barley or intestinal bacteria which can sufficiently degrade cell structure (GRAHAM et al. 1986) (Table 6).

In conclusion, rolled barley showed higher nutritive value compared to hammer milled and if the incidence of gastric lesions caused by small grist size could be depressed by using rolled cereal, then it is preferable from the nutritional point of view. Pelleting improved feed value of barley over the milled form. Expanding had no benefical effect on pellet quality or nutritive value of barley.

Acknowledgements. The author is grateful to Ms. Kirsi Partanen, M. Agr. Sc., for computing the results and to Mr. Pasi Laurinen for the care of the experimental animals. The cooperation with Mr. Juhani Vuorenmaa, M. Agr. Sc. and Ms. Stina Hakulin, Lic. Tech. Sc. in processing the experimental feeds and financial support from Hankkija Rehuteollisuus Oy are greatly acknowledged. 


\section{References}

Åman, P. \& Hesselman, K. 1984. Analysis of starch and other main constituents of cereal grains. Swedish J. Agric. Res. 14: 135-139.

ANDERSEN, P.E \& JUST, A. 1983. Tabeller over fodersoffers sammensaetning m.m. kvaeg, svin. Det kgl. danske Landhusholdningsselskab. Kobenhavn. 102 p.

Bolduan, G. \& Peisker, M. 1992. Wirkung von expandiertem Futter beim Ferkel. Kraftfutter 5/92: 229-232.

DoGgetT, H. 1970. In Sorghum. London, Longmans, Green \& Co. (Ref. Lawrence, T.L.J. 1978.)

Fadel, J.G., Newman, C.W., Newman, R.K. \& Graham, H. 1988. Effects of extrusion cooking of barley on ileal and faecal digestibility of dietary components in pigs. Can. J. Anim. Sci. 68: 891-987.

Graham, H., Hesselman, K., Jonsson, E. \& Åman, P. 1986. Influence of B-glucanase supplementation on digestion of a barley-based diet in the pig gastrointestinal tract. Nutr. Rep. Int. 34: 1089-1096.

Herkelman, K.L., Rodhouse, S.L., Veum, T.L. \& EllerSIECK, M.R. 1990. Effect of extrusion on the ileal and fecal digestibilities of lysine in yellow corn in diets for young pigs. J. Anim. Sci. 68: 2414-2424.

KirChgessner, M., Roth, F.X., Bellwahn, W. \& HeinritZ, K. 1985. Mastleistung, Nährstoffverdaulichkeit und Magenschleimhautveränderung von Schweinen bei unterschliedlicher Futterstruktur. Zbl. Vet. Med. 32: 641-651.

LAWRENCE, T.L.J. 1970. Some effects of including differently processed barley in the diet of the growing pig. 1 . Growth rate, food conversion efficiency, digstibility and rate of passage through the gut. Anim. Prod. 12: 139150.

- 1972. A review of some effects on health and performance of variations in the physical form of the diet of the growing pig. 1. Cereal processing. Vet. Rec. 91: 67-70.

- 1978. Processing and preparation of cereals for pig diets. In: Haresign, W. \& Lewis, D. (eds.). Recent Advances in Animal Nutrition. Butterworths, London. p. 83-98.

- 1983. The effects of cereal particle size and pelleting on the nutritive value of oat-based diets for the growing pig. Anim. Feed Sci. Technol. 8: 91-97.

NĀsI, M. 1984. Nutritive value and metabolic effects of whey protein concentrate and hydrolysed lactose for growing pigs. J. Agric. Sci. Finl. 56: 227-238.

PATTERSON, D.C. 1989. A comparison of various feeding systems for finishing pigs. Anim. Feed Sci. Technol. 26: 251-260.

SAlo, M.-L., Tuori, M. \& KiISKINEN, T. 1990. Rehutaulukot ja ruokintanormit. Helsinki. $70 \mathrm{p}$.

SimONSSON, A. 1978a. Some effects of the fineness of ground barley on the performance of growing pigs. Growth rate, feed conversion efficiency, digestibility and carcass quality. Swedish J. Agric. Res. 8: 75-84.

- 1978b. Some effects of including balrey processed by different mill types in the diet of growing pigs. Growth rate, feed conversion efficiency, digestibility and carcass quality. Swedish J. Agric. Res. 8: 85-105.

— \& BJÖRKLUND, N.-E. 1978. Some effects of the fineness of ground barley on gastric lesions and gastric contents in growing pigs. Swedish J. Agric. Res. 8: 97-106.

Skoch, E.R., Binder, S.F., Deyoe, C.E., Allee, G.L. \& BEHNKE, K.C. 1983. Effects of steam pelleting conditions and extrusion cooking on a swine diet containing wheat middlings. J. Anim. Sci. 57: 929-935.

SNEDECOR, G.W. \& CoChran, W.G. 1967. Statistical methods. 7th ed. 597 p. The Iowa State University Press, Ames, Iowa. USA.

Vanschoubroek, F., Coucke, L. and Van Spaendonck, R. 1971. The quantitative effect of pelleting feed on the performance of piglets and fattening pigs. Nutr. Abstr. Rev. 41: 1-9.

WetTSTein, A. \& WILD, R. 1990. Developments in feed production technology. Roche Symp. on Animal Nutrition and Health. Basel. p. 89-108.

Yen, J.T., Baker, D.H., Harmon, B.G. \& Jensen, A.H. 1971. Corn gluten feed in swine diets and effect of pelleting on tryptophan availability to pigs and rats. J. Anim. Sci. 33: 1012-1016.

\section{Manuscript received August 1992}

Matti Näsi

University of Helsinki

Department of Animal Science

SF-00710 Helsinki, Finland 


\title{
SELOSTUS
}

\section{Jauhatustavan, rakeistuksen ja ekspanderkäsittelyn vaikutus ohran rehuarvoon lihasian ruokinnassa}

\author{
MATTI NÄSı
}

Helsingin yliopisto

Tutkimuksessa selvitettiin vasaramyllyjauhatuksen ja litistyksen, rakeistuksen sekă ekspanderkäsittelyn vaikutusta lihasioille syötettävän ohran ravintoaineiden sulavuuteen ja valkuaisen hyväksikäyttöön. Tutkimus tehtiin $2 * 2 * 2$ faktorikokeena $8 * 8$ latinalaisen mallin mukaan 29 - $97 \mathrm{~kg}$ elopainoisilla lihasioilla. Litistetyn ohran partikkelikoko ali keskimäärin suurempaa kuin vasaramyllyjauhetun. Rakeistus ja ekspanderkäsittely pienensivăt partikkelikokoa. Litistettyä ohraa käytettäessä rakeiden laatu oli heikompi kuin vasaramyllyjauhettua käytettäessä. Ekspanderkäsittelyllä ei ollut parantavaa vaikutusta rakeiden kestävyyteen. Litistetyn ohran raakaproteiinin sulavuus oli parempi kuin jauhetun. Rakeistus paransi ohran kaikkien ravintoaineiden sulavuuksia keskimäärin 0.02. Ekspanderkäsittely paransi raakakuidun sulavuutta. Rakeistuksen ja ekspanderkäsittelyn sekă jauhamistavan välillä oli sulavuudessa yhdysvaikutuksia. Litistettyä ohraa saaneet siat pidättivät enemmän typpeä ja valkuaisen hyvăksikảyttő oli tehokkaampaa kuin vasaramyllyjauhettua saaneilla. Rakeistus paransi valkuaisen imeytymistä, mutta sillä ei ollut vaikutusta typen pidättymiseen. Ekspanderkäsittely ei vaikuttanut valkuaisen imeytymiseen eikä typen pidättymiseen. 